\title{
Reconstruction of the proximal ends of retiolitid rhabdosomes (Graptolithina) from the Upper Wenlock and the Lower Ludlow
}

\author{
Kinga Dobrowolska
}

Received: 23 April 2012/Accepted: 16 July 2012/Published online: 28 August 2012

(C) The Author(s) 2012. This article is published with open access at Springerlink.com

\begin{abstract}
Detailed study of the ultrastructures on the cortical lists of retiolitids occurring after the lundgreni event has been undertaken. The extremely well preserved material from the Gołdap borehole of Poland (Baltica) enables classification of clathrial lists into two types-with single and double seams. Significantly different seam development is observed between two groups of retiolitids occurring before and after the lundgreni event. The study of seams and increments on the lists enables reconstruction of the membrane arrangement of the rhabdosomes. Reconstruction of the proximal ends, the arrangement of the ancora umbrella, and the layout of the proximal ventral and lateral orifices of five genera, Neogothograptus, Holoretiolites, Plectograptus, Spinograptus, and Quattuorgraptus n. gen., is presented. The new genus Quattuorgraptus is separated from Spinograptus because of the different development of the ancora umbrella and the width of the lateral walls of the rhabdosome.
\end{abstract}

Keywords Ancora umbrella - Membrane - Retiolitidae · Graptolites · Proximal end · Silurian

Kurzfassung Detailierte Untersuchungen der Feinstrukturen der kortikalen Leisten der Retioliten aus dem Zeitbereich nach dem lundgreni Ereignis (Oberes Wenlock-Ludlow) wurden vorgenommen. Sehr gut erhaltetes Material aus der Gołdap Bohrung in Polen (Teil von Baltica im Paläozoikum) erlaubt die Unterscheidung der klathrialen Leisten aufgrund ihrer Bauweise in zwei Typen: Leisten mit Einzel- und mit Doppelnähten. Diese wichtige

K. Dobrowolska $(\square)$

Instytut Paleobiologii PAN, ul. Twarda 51/55,

00-818 Warszawa, Poland

e-mail: kdobrowolska@twarda.pan.pl
Differenzierung in der Nahtentwicklung ist zwischen den Retioliten vor und nach dem lundgreni Ereignis zu beobachten. Die Untersuchungen der Leisten und der Anwachsmarkierungen der Fuselli an den Nähten erlauben die Rekonstruktion der nicht erhaltenen Membranen des Rabdosomes. Die Rekonstruktion der Proximalentwicklung, die Entwicklung der Ankorakuppel, sowie die Anordnung der ventralen und lateralen Öffnungen der fünf Gatungen Neogothograptus, Holoretiolites, Plectograptus, Spinograptus, and Quattuorgraptus werden diskutiert. Die neue Gattung Quattuorgraptus wird aus der Gattung Spinograptus ausgegliedert, da sich die Entwicklung der Ankorakuppel und die Breite der lateralen Wänden des Rabdosomes von Spinograptus deutlich unterscheidet.

Schlüsselwörter Ancore Umbrella - Membran . Retiolitidae · Graptolithen · Proximale Ende · Silur

\section{Introduction}

The early Paleozoic Graptolithina were of significant importance as plankton in the marine biocenosis. Their Silurian family Retiolitidae evolved rapidly from the Aeronian to the Ludfordian. The retiolitids were a peculiar group of colonial graptolitids characterized by the unique structure of their rhabdosome. All graptolites had a thecal rhabdosome. However, for the retiolitids it was internal, because outside they had an additional layer: the ancora sleeve, i.e. a structure developed from the bifurcation and subsequent distal development of the virgella. Another specificity was the construction of rhabdosomal walls. The walls of graptolite rhabdosomes consisted of an internal fusellar layer and an external cortical layer, the latter consisting of bandages, whereas the walls of retiolitids 
consisted of cortical lists and membranes which were stretched between them. The membranes of the ancora sleeve and thecal walls were extremely thin. In contrast, the lists, which were much thicker, were built of multilayered cortical bandages and are usually well preserved (Kozłowska-Dawidziuk 2004). Usually, the rhabdosome looks like a regular network of lists, although sometimes the whole rhabdosome (lists and membranes) is preserved (Lenz 1994a, b; Lenz and Thorsteinsson 1997; KozłowskaDawidziuk 1997; Lenz and Kozłowska-Dawidziuk 2002). For a long time, the arrangement of the membranes was a mystery. However, if scanning electron microscopy (SEM) is used to view specimens of retiolitids, traces of the membranes on the cortical lists can be seen as prominent seams (Bates 1987). Nowadays, it is usually possible to reconstruct the membranes on the basis of seams occurring on the lists. Bates and Kirk $(1978,1992,1997)$ described in some detail development of the ancora umbrella in Stomatograptus, Pseudoretiolites, Gothograptus nassa, Holoretiolites mancki, and Retiolites. Reconstruction of the membranes' position on the basis of the seam arrangement of the ancora umbrella of the genus Plectograptus was presented by Bates et al. (2006), without detailed studies of seams around the proximal ventral and lateral orifices.

It is commonly accepted that the mode of development and proximal structures are the best features for recognition of high-level taxonomic categories within the Graptoloidea (Mitchell 1987; Kozłowska-Dawidziuk et al. 2003). For the retiolitids, the mode of development and, particularly, the development of the ancora umbrella with location of the proximal lateral and ventral orifices are characteristic features of each genus. This is probably because the ancora umbrella started its development during the early stages of the astogeny of the colony.

To better understand changes of astogeny, evolution, and retiolitid behavior connected with the construction of rhabdosomes it is very important to know the structure of the entire rhabdosome including details of the membrane arrangement. The purpose of this paper is threefold:

- to present a classification for clathrial seams of retiolitids occurring after the lundgreni event;

- to reconstruct membranes of the proximal end of rhabdosomes for four genera: Neogothograptus, Holoretiolites, Plectograptus, Spinograptus; and

- to present a new genus, Quattuorgraptus, separated from Spinograptus on the basis of differences in ancora umbrella development.

\section{Materials and methods}

The new material was derived from the Gołdap borehole located in the Polish part of the East European Platform
(Fig. 1). The one specimen used for constructing the model of the ancora umbrella membranes of Spinograptus is from an erratic boulder from Jarosławiec. The material is very rich and contains well preserved specimens of different species from different astogenetic stages. The retiolitids were recovered after slow dissolution of carbonates in hydrochloric acid (1-10\%). A fine hairbrush was used to pick up and transfer specimens. The material was stored either in glycerine in plastic containers or on the SEM stubs.

\section{Ultrastructure of the retiolitid rhabdosomes}

The ultrastructures occurring on the rhabdosomal lists indicate the presence and course of the membranes. There can be seams and increments which are remains of fuselli and small fragments of membranes (Fig. 2).

Bates and Kirk $(1992,1997)$ described the ultrastructures of Llandovery ancorate diplograptids and retiolitids occurring before the lundgreni event with remarkable accuracy. They observed enwrapping and insertion seams. The insertion seam can be equivalent to a single seam on lists of the young retiolitids occurring after the lundgreni event. The double seam described in this paper can comprise an enwrapping seam on one side of the list and an insertion seam on the other. However, on the basis of observations of the post-lundgreni material from the Gołdap borehole and the pre-lundgreni material from the Bates and Kirk $(1992,1997)$ papers, it is difficult to compare the seams of the earlier and later retiolitids because they differ in appearance. The seams of the earlier are distinct and deep, those of the later retiolitids are less pronounced and shallow, and it is easy to confuse them with bandages. The increments of old retiolitids are more often preserved than those of young retiolitids.

Bates et al. (2006) described the primary lists of the ancora sleeve in Plectograptus. Two different types of primary list (A and B) are found in this genus (Bates et al. 2006, Fig. 5). The type A lists include the ancora sleeve lists without pleural lists, the type B lists build pleural lists. The initial list of the type A lists has a proximally-facing insertion seam (Bates et al. 2006, Fig. 5a) which marks the extension of the initial fusellum of the ancora sleeve. The type B lists have an initial core (Bates et al. 2006, Fig. 5b) which is similar to the fusellar core of the spines, and is surrounded by concentric asymmetric cortical layers.

On the basis of the new material from the Gołdap borehole, containing five genera of retiolitids (Neogothograptus Kozłowska-Dawidziuk, 1995; Holoretiolites Eisenack, 1951; Plectograptus Moberg and Törnquist, 1909; Spinograptus Bouček and Münch, 1952 and Quattuorgraptus $\mathrm{n}$. gen.), two different types of seam occurring on 
Fig. 1 Sketch map showing the location of the Gołdap IG 1 borehole within the late Wenlock facies framework across the western margin of the East European Platform (modified after Tomczykowa and Tomczyk 1979)

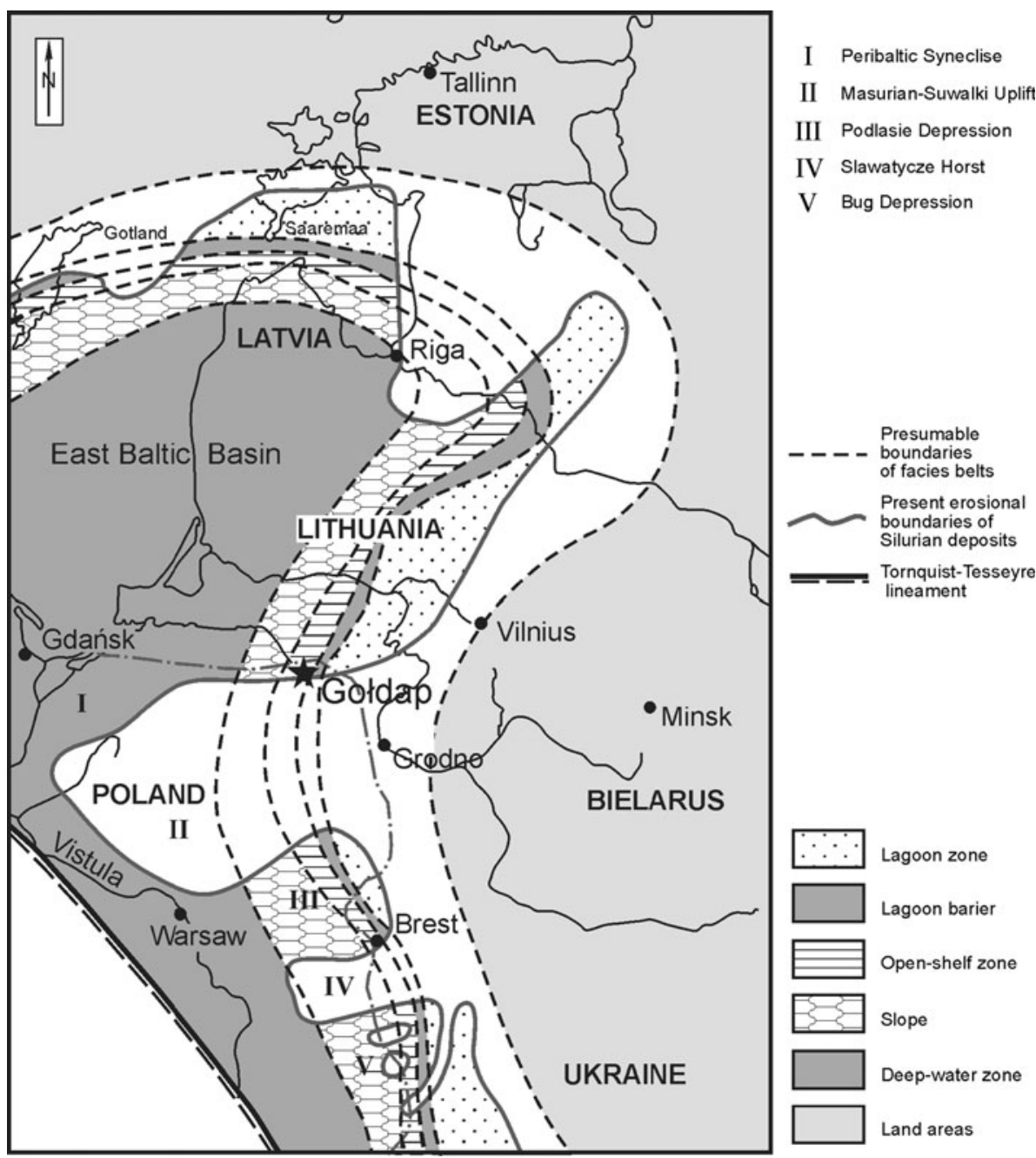

I Peribaltic Syneclise

III Podlasie Depression

IV Slawatycze Horst

V Bug Depression

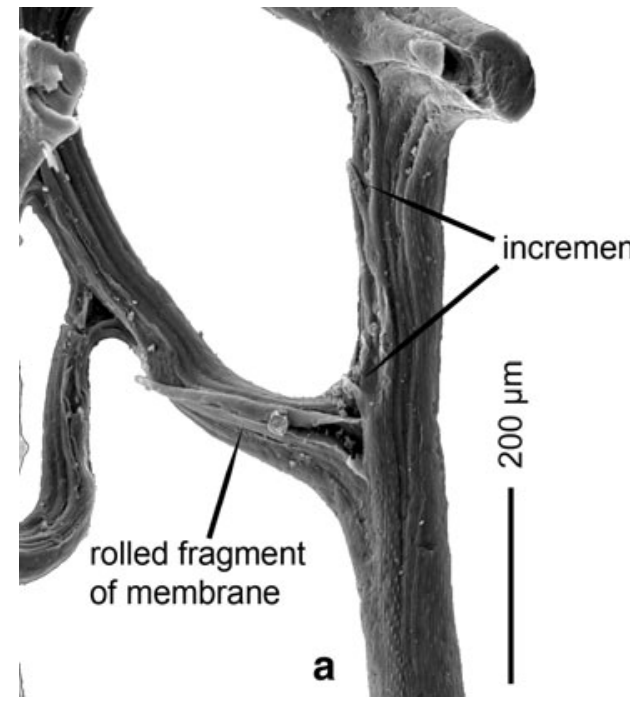

Fig. 2 Types of ultrastructure occurring on the lists of the retiolitid rhabdosomes. a Fragment of the rhabdosome of Plectograptus macilentus (Törnquist, 1887) with enrolled fragment of the membrane and increments. ZPAL G. 48/1. b Fragment of the ancora umbrella of Quattuorgraptus munchi (Eisenack, 1951) with increments on the

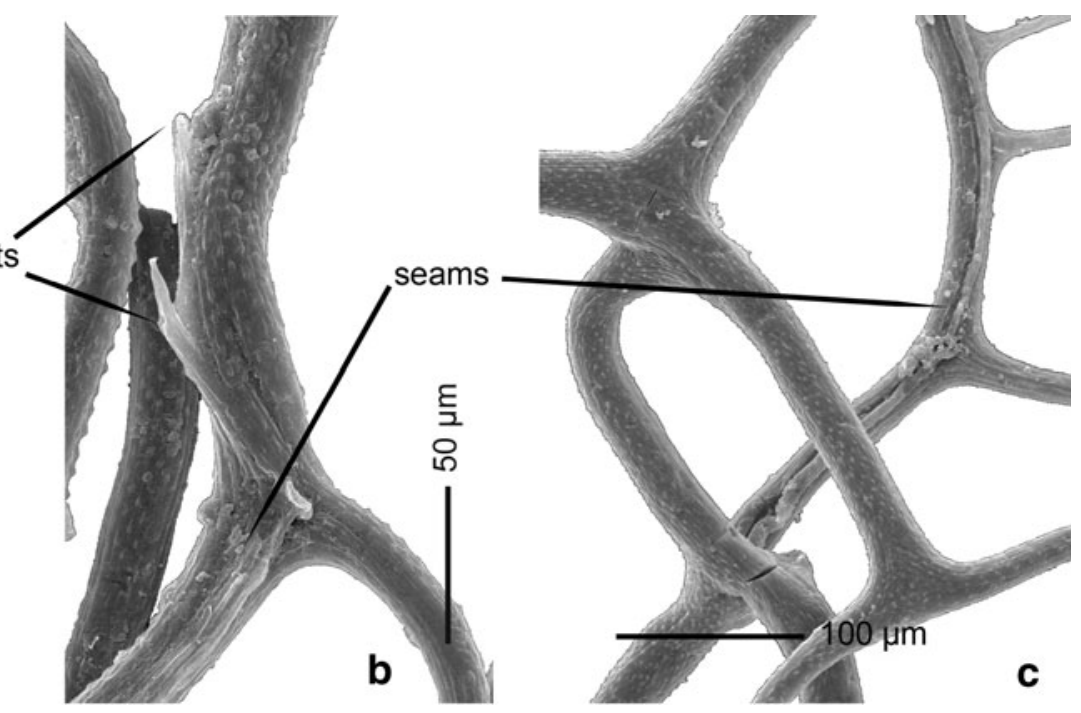

ancora umbrella rim and double seams on the list of the ancora umbrella. ZPAL G. 48/2. c Fragment of the rhabdosome of Spinograptus clathrospinosus (Eisenack, 1951) with well developed double seam on the lateral apertural rod. ZPAL G. 48/3 
the clathrium lists were found: single seams and double seams (Fig. 3). The double seam on a list indicates two membranes connected to the list extending in two different directions (Fig. 3a-b) whereas a single seam indicates a single membrane connected to the list (Fig. 3c-d). This classification of seams can be partly correlated with the types of the list found in the material described by Bates et al. (2006). In the material from the Gołdap borehole, the double seams are similar to the type A lists of Bates et al. (2006): in the cross section, a distinct notch of a proximally-facing seam runs along the list indicating the first membrane whereas the second membrane runs on the other side of the list (Fig. 3a). However, the notch may not be visible on the list and then the list with double seam has an initial core and successive layers of bandage (Fig. 3b). The single seam has a notch around which concentric bandage layers are arranged (Fig. 3c). Sometimes, a fragment of membrane can be observed in the notch (Fig. 3d). It is similar to the type B primary lists of Bates et al. (2006) but single lists from the material from the Gołdap borehole do not have such a distinct initial core (Fig. 3c-d) as in the type B lists (Bates et al. 2006, Fig. 5b), however, both have concentric asymmetric cortical layers. So far, the A and B types of lists have not been observed in all clathrial lists of the rhabdosome but only in the ancora sleeve lists. The difference in interpretation of seams between the Gołdap borehole material and that of Bates et al. (2006) (the erratic boulders from northern Germany and Poland, nodules from Arctic Canada) may be because of different preservation of the retiolitid material. The study of seams is quite a laborious task full of technical problems. First, the state of preservation of material may not enable correct interpretation because some elements may not be revealed. Second, only fully developed mature specimens are appropriate for investigations because young colonies have thin lists with poorly developed ultrastructures, for example seams (Fig. 4). Last, but not least, sometimes seams can easily be mistaken for thick cortical bandages. Therefore, before deciding where the seam is located it is important to trace it along the entire list.

Lists with double and single seams differ from each other not only in cross section but also in the view from the seam side. A well preserved list with a single seam has a clearly visible notch on the entire length of the list (Fig. 5a) and a round core of the initial list can be easily seen on a list with a double seam (Fig. 5b).

The elements of the clathrium with double seams include: ancora sleeve lists except pleural lists, ancora umbrella lists without ancora umbrella rim, and lateral apertural rods, genicular lists, whereas the elements with single seams include pleural lists and lips. Depending on the position of the rim of the ancora umbrella in the rhabdosome it may have either double or single seams. If over a given fragment of the
Fig. 3 Cross sections of lists with different types of seam occurring on clathrial lists, and reconstructions of membranes. $\mathbf{a}_{\mathbf{1}}$ Double seam of the ancora sleeve with distinct notch (arrow) on the list of Plectograptus macilentus (Törnquist, 1887). $\mathbf{a}_{2}$ reconstruction. $\mathbf{b}_{1}$ Double seam of the ancora sleeve with initial core and successive layers of bandages without notch in Plectograptus macilentus (Törnquist, 1887). $\mathbf{b}_{2}$ reconstruction. $\mathbf{c}_{\mathbf{1}}$ Single seam with clear notch (arrow) of lip of Holoretiolites manckoides Kozłowska-Dawidziuk, 1995. $\mathbf{c}_{\mathbf{2}}$ reconstruction. $\mathbf{d}_{\mathbf{1}}$ Single seam of pleural list with fragment of the membrane of Plectograptus macilentus (Törnquist, 1887). $\mathbf{d}_{\mathbf{2}}$ reconstruction. a, b, d specimen ZPAL G. 48/4; c specimen ZPAL G. 48/5. Scale bars $20 \mu \mathrm{m}$

ancora umbrella rim, a proximal orifice can be found, this part of the ancora umbrella rim has a single seam, otherwise it has a double one. In some mature specimens, the proximal orifices can be overgrown by reticulum and membranes. In such cases the ancora umbrella rim under these orifices has the double seams. The main ancora umbrella lists have double seams but usually they look slightly different from the remaining lists with double seams. Lists with double seams have an oval core between the two seams (Fig. 5b). This element in the lists of the ancora umbrella is more flat and often has small, ragged pieces of membranes (Fig. 6). This may be because the membrane of the ancora umbrella was secreted outside the lists whereas membranes of the other part of the rhabdosome were secreted inside (Kozłowska-Dawidziuk and Lenz 2001). The latter may be associated with the fact that the ancora umbrella was secreted by the siculozooid which could differ from that of the other zooids, or could behave differently as a result of a unique way of building the ancora umbrella.

\section{Membrane reconstruction of the proximal ends of retiolitid rhabdosomes occurring after the lundgreni event}

The proximal end of the retiolitid rhabdosome is comprised of such structures as ancora umbrella with its membranes, proximal ventral orifices, proximal lateral orifices (Fig. 7), and outer ancora. In this paper the outer ancora is not taken into consideration because it is an additional, reticular structure occurring usually in mature specimens. Lists of the ancora umbrella can be divided into the main lists of the ancora umbrella having seams on the external side of the rhabdosome and the ancora umbrella rim surrounding the main lists (Fig. 8).

The proximal ventral orifices belonging to the ventral walls are bounded proximally by portions of the ancora umbrella rim (Fig. 9b-d) or membrane in Plectograptus at the theca $1^{2}$ side of the rhabdosome (Figs. 7a, 9a), laterally by the most proximal pleural lists, and distally by the genicular lists of the first pair of thecae (Figs. 7, 9) (Bates et al. 2006). 

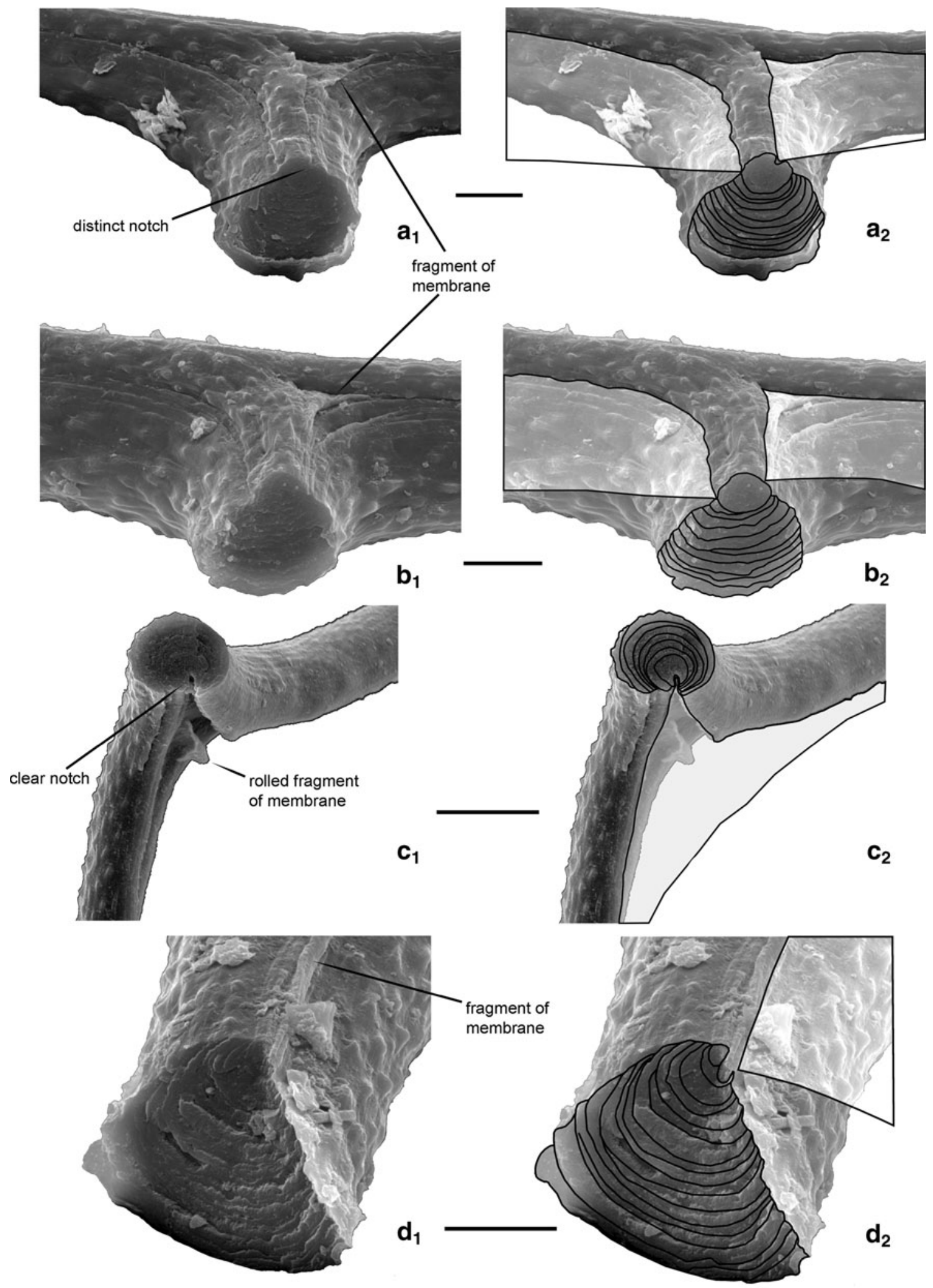

reconstructed membrane 


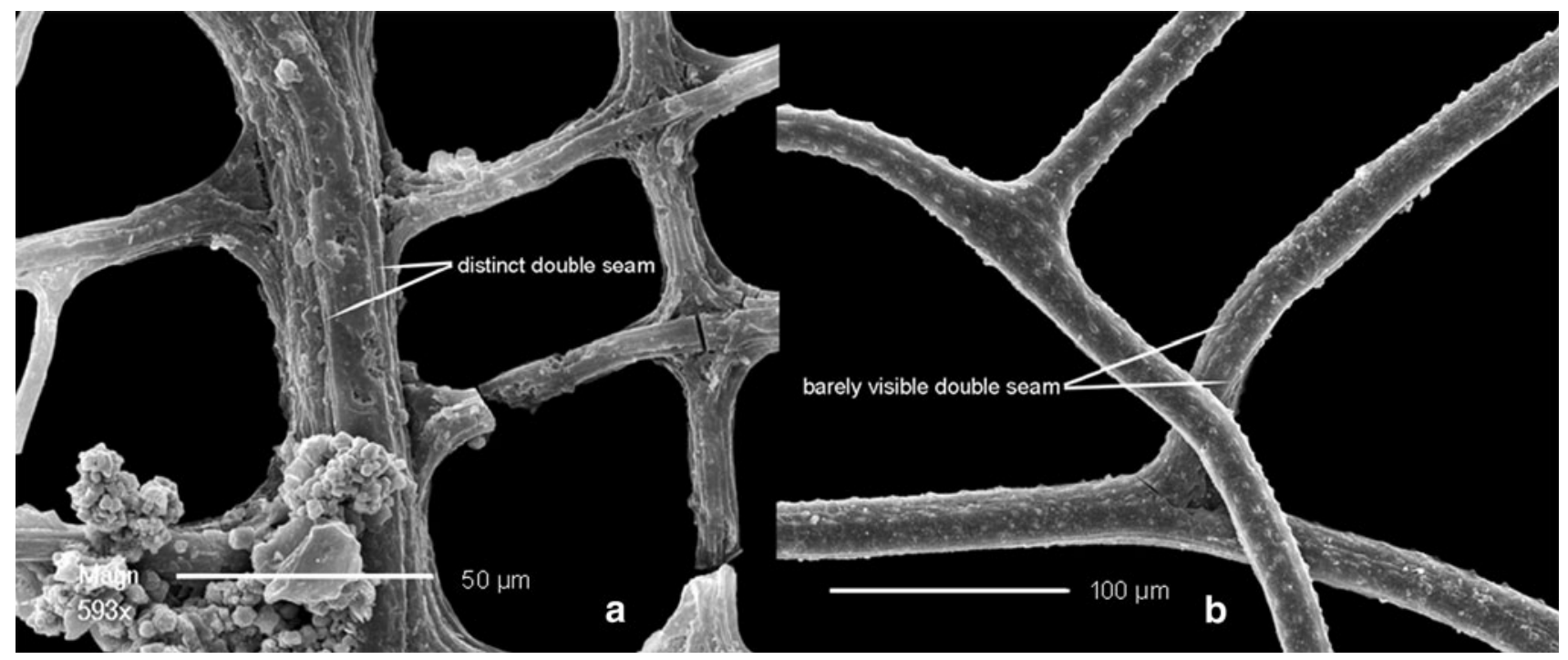

Fig. 4 The different appearance of seams of young and mature colonies. a Mature specimen of Neogothograptus reticulatus Kozlowska Lenz, and Melchin, 2009 with distinct double seam of the ancora sleeve. ZPAL G. 48/6. b Young specimen of Plectograptus mobergi, Bates, Kozłowska, Maletz, Kirk, and Lenz, 2006 with barely visible double seam of the ancora sleeve. ZPAL G. 48/7

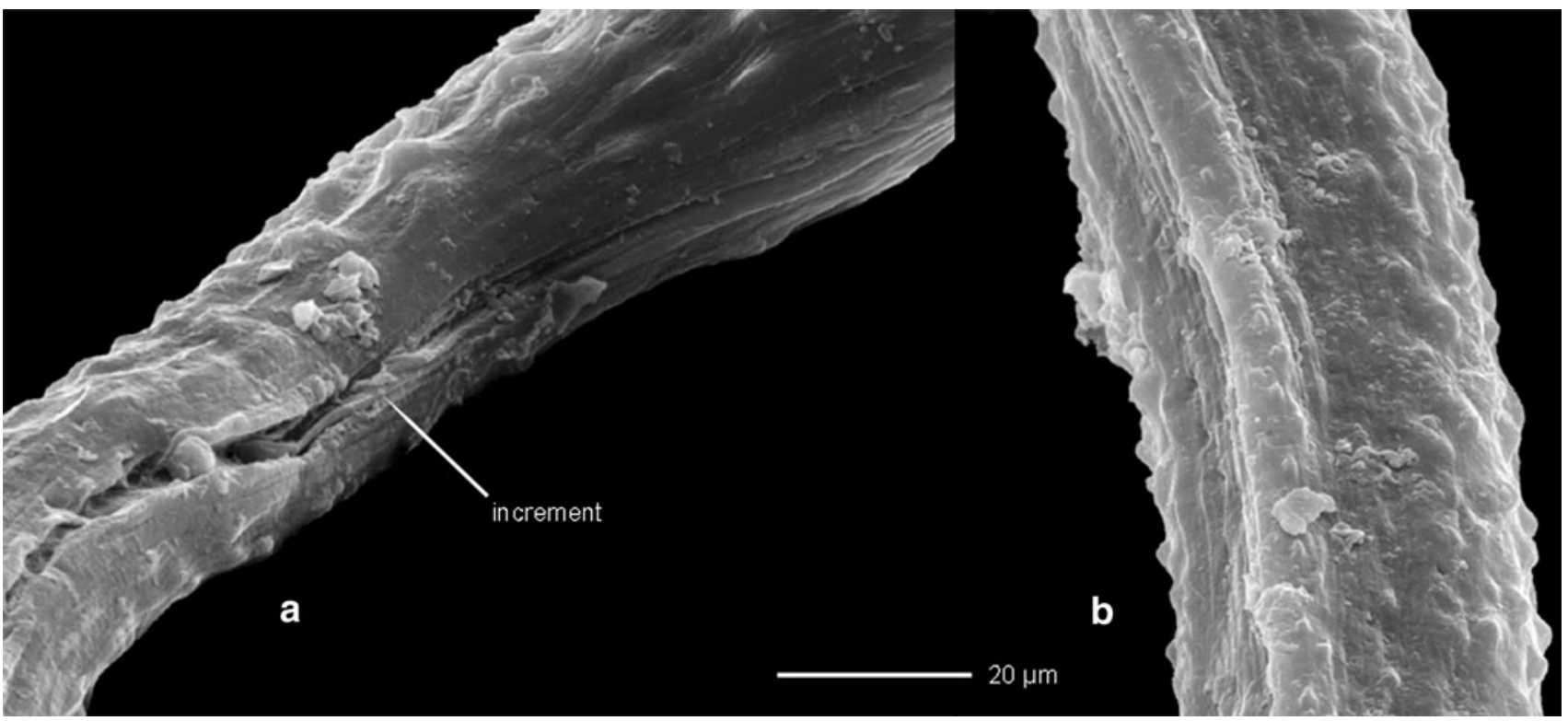

Fig. 5 Single (a) and double (b) seams from the seamward side of the lists of Plectograptus macilentus (Törnquist, 1887). ZPAL G. 48/4

The proximal lateral orifices belonging to the lateral walls are bounded proximally by part of the ancora umbrella rim, and laterally and distally by the ancora sleeve lists in Neogothograptus, Holoretiolites, and Spinograptus (Fig. 9b-c). In Plectograptus, these orifices are bounded proximally by membranes of the ancora umbrella or, in rare cases, by part of the ancora umbrella rim and distally by the ancora sleeve membranes (Figs. 7, 9a). In Quattuorgraptus, the lateral orifices are surrounded proximally by the ancora umbrella rim, distally by the ancora sleeve lists, and, at the theca $1^{2}$ side of the rhabdosome, by pleural lists below the first pair of thecae (Fig. 9d).

Here, the ultrastructures appearing on lists in the proximal end of the retiolitids from the Upper Wenlock and the Lower Ludlow from the Gołdap borehole are analyzed in detail. On the basis of the classification of the observed seams, the development of the ancora umbrella can be reconstructed, with the location of the proximal ventral and lateral orifices and the course of the membranes of the proximal ends of the rhabdosomes, for five genera of retiolitids. Because of detailed analysis of seams of the 

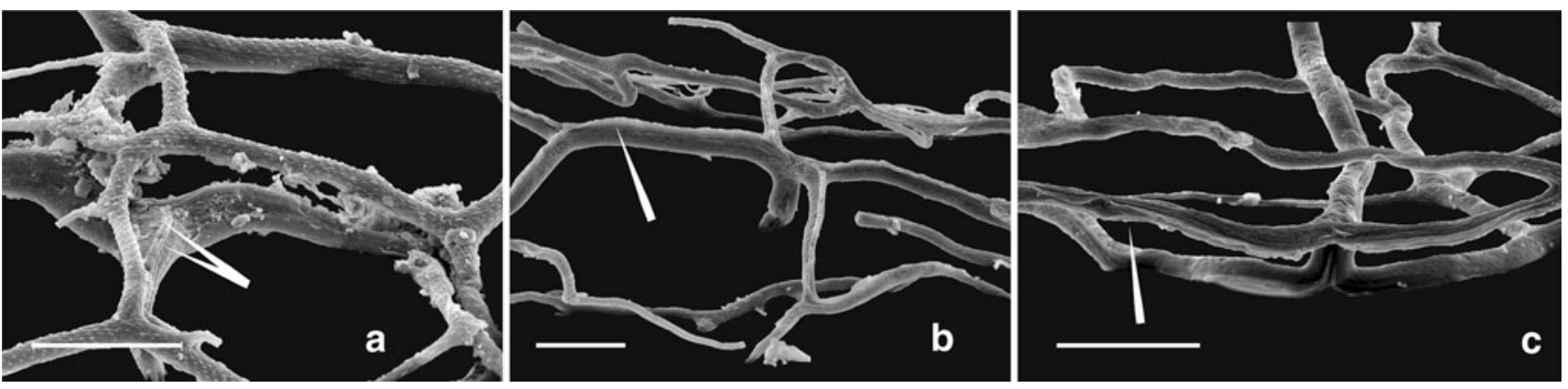

Fig. 6 The double seams of the ancora umbrella with fragments of the ancora umbrella membranes (arrows) in different genera. a The ancora umbrella and outer ancora of the Neogothograptus ornatus Maletz, 2008. ZPAL G. 48/8. b The ancora umbrella of Spinograptus clathrospinosus (Eisenack, 1951). ZPAL G. 48/9. c The ancora umbrella of Spinograptus spinosus (Wood, 1900). ZPAL G. 48/10. Scale bars $100 \mu \mathrm{m}$
Fig. 7 a Model of the arrangement of the ancora umbrella membranes and the ancora sleeve membranes, without thecal membranes. The membranes of the ancora sleeve are only shown on the reverse side of the rhabdosome. Model specimens of Plectograptus macilentus (Törnquist, 1887). b Mature rhabdosome with eight pairs of thecae, and broken and displaced ancora umbrella. ZPAL G. 48/11. c The ancora umbrella of a mature rhabdosome with fragment of the ancora umbrella rim. ZPAL G. $48 / 4$ constructed on the basis of two

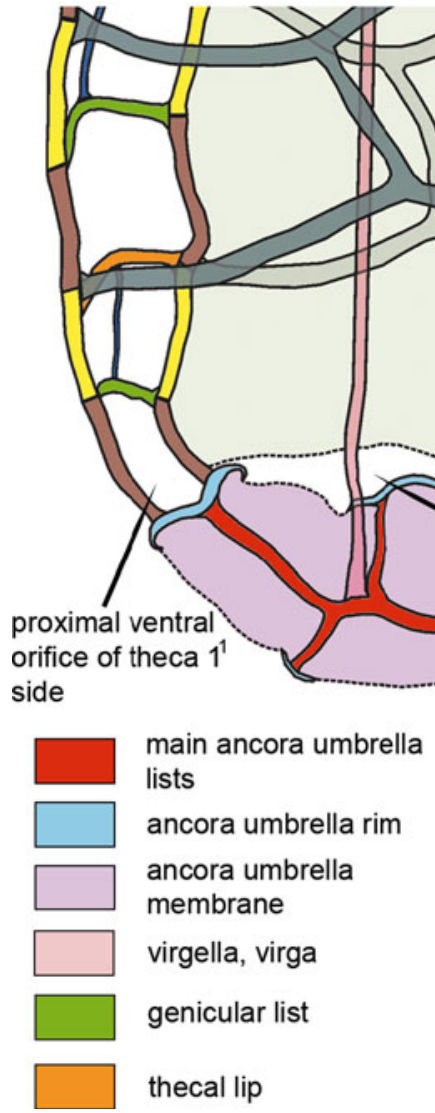

species Sp. munchi, it was also possible to erect a new genus, Quattuorgraptus. For each diagnosis of the described genera, a detailed description of the proximal end of the rhabdosome is given on the basis of the ultrastructures occurring on lists of the ancora umbrella and on lists surrounding the proximal lateral and ventral orifices.

\section{Systematic palaeontology}

Terminology according to Bates et al. 2005.

Family Retiolitidae Lapworth, 1873
Subfamily Plectograptinae Bouček and Münch, 1952 Genus Neogothograptus Kozłowska-Dawidziuk, 1995

Type species Neogothograptus purus Kozłowska-Dawidziuk, 1995

Diagnosis (emended from Maletz 2008) Ancora umbrella thicker than the rest of rhabdosomal lists in mature forms, consisting of three short branches and one long branch divided twice, usually at theca $1^{2}$ side of the rhabdosome; ancora umbrella has six meshes and fully developed ancora umbrella rim; outer ancora usually present in mature 
Fig. 8 The ancora umbrella and the reconstruction of the arrangement of the ancora umbrella membranes for four genera. Numbers show the number of meshes of the ancora umbrella. a Neogothograptus romani Kozłowska-Dawidziuk, 1995. ZPAL G. 48/12.

b Holoretiolites manckoides Kozłowska-Dawidziuk, 1995. ZPAL G. 48/5. c Plectograptus macilentus (Törnquist, 1887). ZPAL G. 48/13. d Spinograptus clathrospinosus (Eisenack, 1951). ZPAL G. 47/11. Scale bars $200 \mu \mathrm{m}$
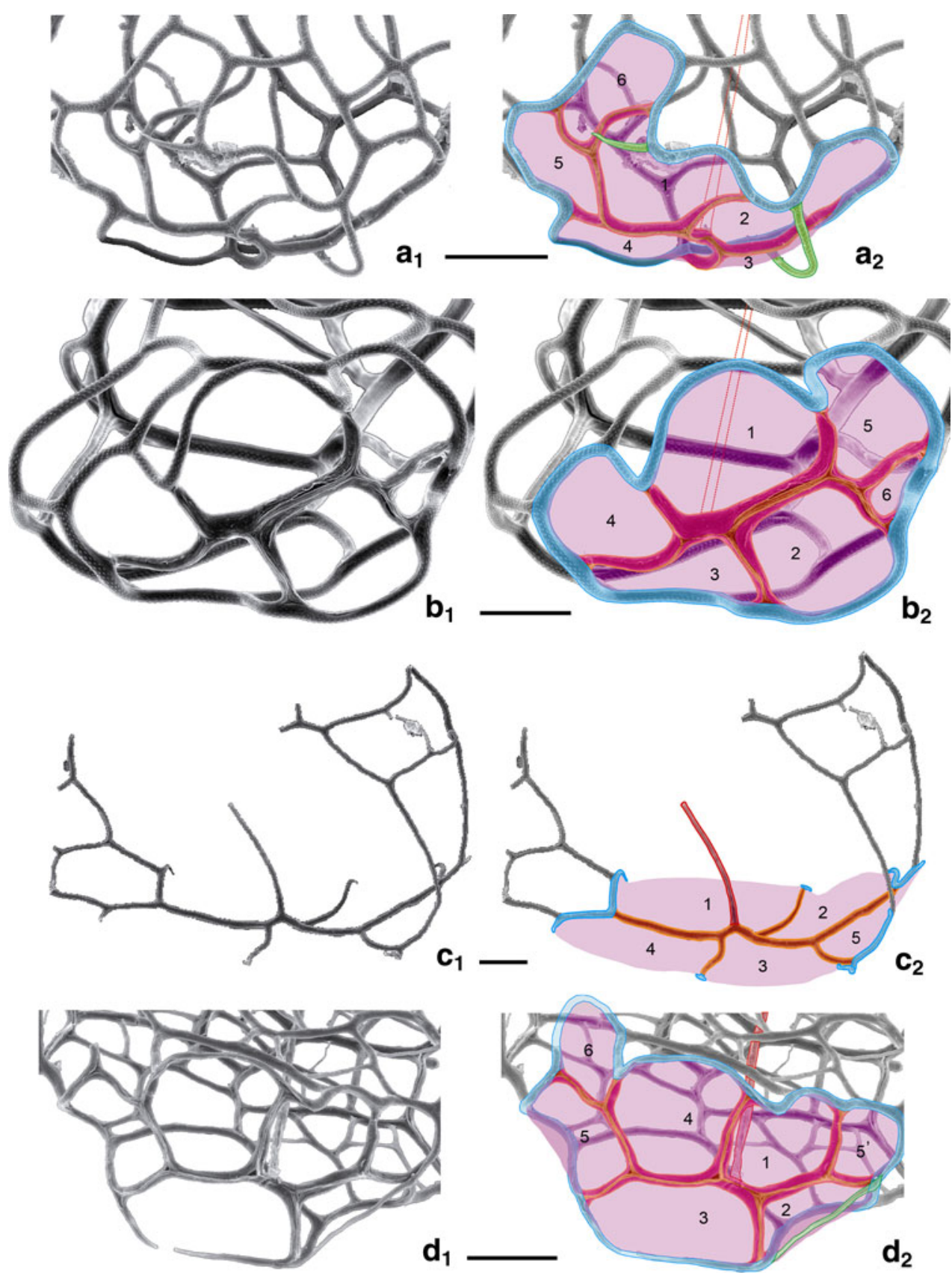

main ancora umbrella lists

ancora umbrella rim

ancora umbrella membrane virgella, virga

outer ancora specimens; nema located centrally; proximal ventral orifices and proximal lateral orifices may be overgrown by reticulum in mature specimens. Ventral wall consists of lips, genicular lists, lateral apertural rod, and mid-ventral lists; genicular processes present in most species; reticulum development highly variable; rhabdosome ended by appendix.
Included species Retiolites balticus Eisenack, 1951; Neogothograptus purus Kozłowska-Dawidziuk, 1995; Neogothograptus purus labiatus Lenz and KozłowskaDawidziuk, 2004; Neogothograptus romani KozłowskaDawidziuk, 1995; Neogothograptus alatiformis Lenz and Kozłowska-Dawidziuk, 2004; Neogothograptus melchini Lenz and Kozłowska-Dawidziuk, 2004; Neogothograptus 
Fig. 9 Reconstructions of the ancora umbrella mesh development and geometry from the proximal end for all the genera discussed. The seams on the ancora umbrella marked in black. The numbers show amounts of meshes of the ancora umbrella. Figures are not to scale. a Plectograptus (Bates et al. 2006, modified).

b Neogothograptus and

Holoretiolites. c Spinograptus. d Quattuorgraptus
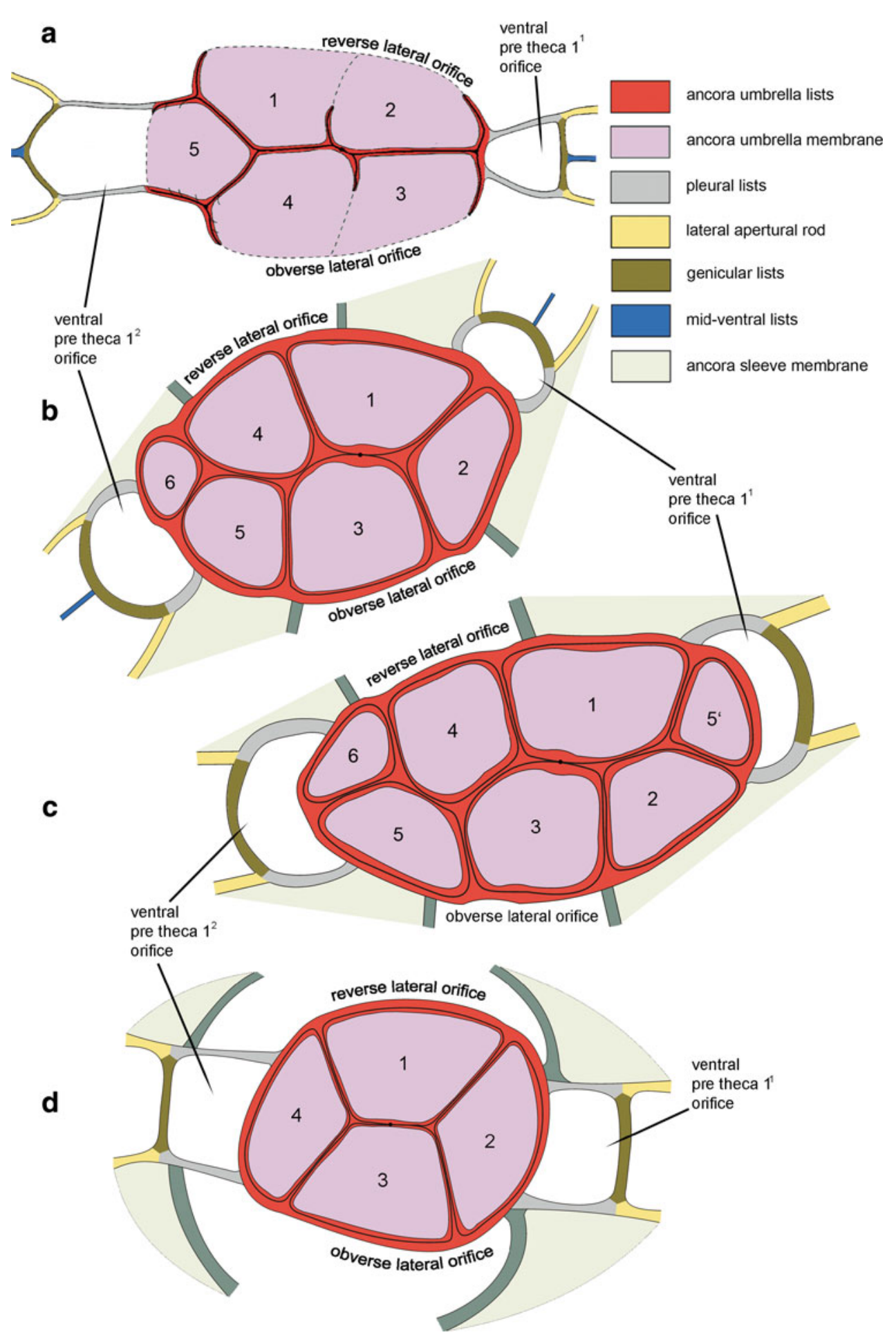

thorsteinssoni Lenz and Kozłowska-Dawidziuk, 2004; Neogothograptus eximinassa Maletz, 2008; Neogothograptus ornatus Maletz, 2008; Neogothograptus reticulatus Kozłowska, Lenz and Melchin, 2009.

Remarks On the basis of very rich material of Neogothograptus from the Gołdap borehole, comprising
$N$. balticus, $N$. purus, $N$. romani, $N$. alatiformis, $N$. eximinassa, $N$. ornatus and $N$. reticulatus, the proximal end of the rhabdosome is described. In 2008 Maletz reported that branches of the ancora umbrella divide the space of the ancora umbrella into seven meshes. However, after examining the seams of the ancora umbrella, it was discovered that the ancora umbrella has six meshes (Figs. 8a, 

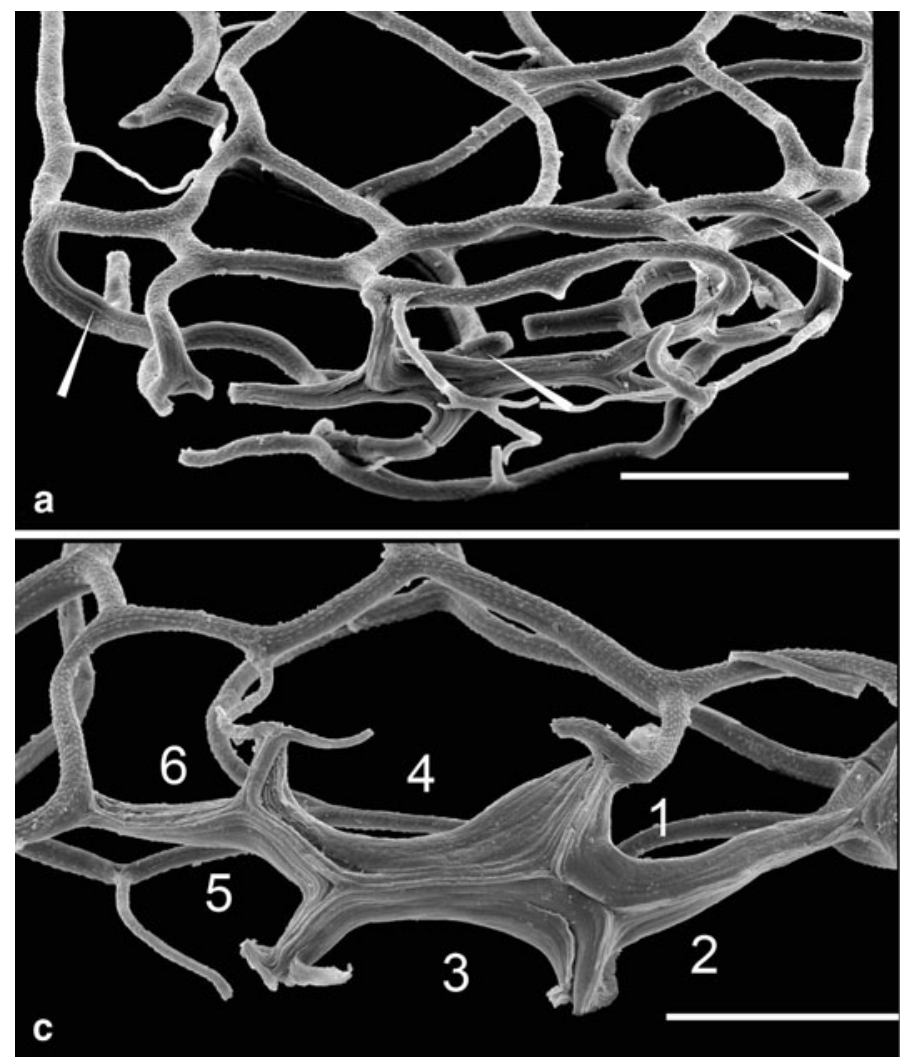

Fig. 10 Proximal ends of Neogothograptus Kozłowska-Dawidziuk, 1995 and Spinograptus Bouček and Münch, 1952. a Seams indicating the probable existence of the membranes (arrows) overgrowing the proximal ventral and lateral orifices in Neogothograptus. ZPAL G. 48/14. b Proximal view of the young rhabdosome of Neogothograptus ornatus Maletz, 2008. ZPAL G. 48/23. c Proximal view of the mature

$9 \mathrm{~b}, 10 \mathrm{a}-\mathrm{c})$. The proximal ventral orifices and the proximal lateral orifices were probably overgrown by the membranes because over the ancora umbrella only the lists with double seams have occurred (Fig. 10a). In some species, N. alatiformis, $N$. eximinassa, and $N$. reticulatus, these orifices were also overgrown by reticulum. Lenz and KozłowskaDawidziuk (2004) described also N. alatiformis with proximal ventral and lateral orifices overgrown by reticulum in mature rhabdosomes. The rhabdosomes at early stages of astogeny development have proximal orifices which are not overgrown by reticulum and probably by membrane, but seams of these specimens are less pronounced, making it impossible to determine this very feature.

Genus Holoretiolites Eisenack, 1951

Type species: Retiolites mancki Münch, 1931

Diagnosis (emended from Kozłowska-Dawidziuk 1995) Ancora umbrella consists of three short branches and one long branch divided twice located at the theca $1^{2}$ side of the rhabdosome; branches of ancora umbrella form six meshes; ancora umbrella rim is fully developed; outer
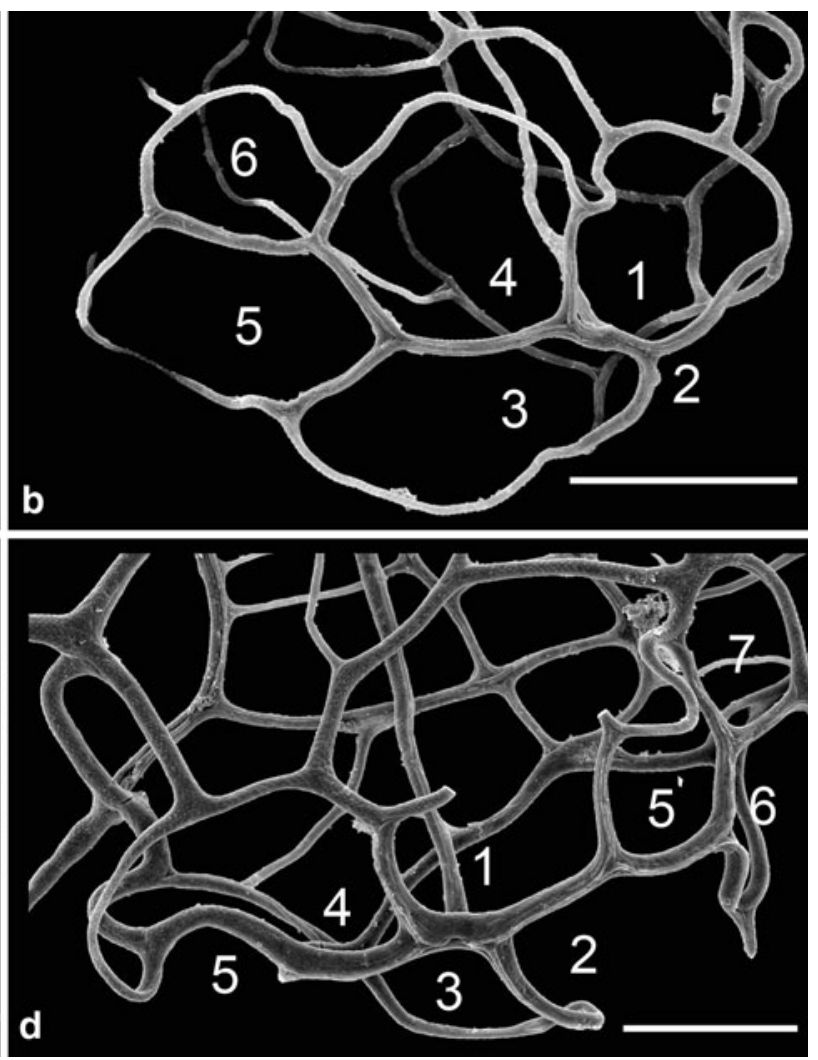

rhabdosome of Neogothograptus purus Kozłowska-Dawidziuk, 1995. ZPAL G. 48/24. d The aberrant form of the ancora umbrella of Spinograptus clathrospinosus (Eisenack, 1951) with an additional branch at the theca $1^{2}$ side of the rhabdosome and with eight meshes. ZPAL G. 48/3. Scale bars $200 \mu \mathrm{m}$. a-c Numbers show the amounts of meshes of the ancora umbrella

ancora developed only in $H$. erraticus; nema located centrally. Ventral wall consists of lips, genicular lists, and fully developed mid-ventral lists in $H$. mancki, H. manckoides, and $H$. erraticus, reduced in $H$. helenaewitoldi and $H$. atrabecularis; no genicular processes; reticulum present only in $H$. erraticus; rhabdosome ended by appendix.

Included species Retiolites mancki Münch, 1931; Retiolites erraticus Eisenack, 1951; Holoretiolites manckoides Kozłowska-Dawidziuk, 1995; Holoretiolites atrabecularis Kozłowska-Dawidziuk, 1995; Holoretiolites helenaewitoldi Kozłowska-Dawidziuk, 2004.

Remarks The arrangement of the ancora umbrella is described on the basis of rich material including the species: $H$. mancki, $H$. erraticus, $H$. manckoides, $H$. atrabecularis, and $H$. helenaewitoldi. The ancora umbrella of Holoretiolites is similar to that of Neogothograptus (Figs. 8a-b, 9b). Holoretiolites differs from Neogothograptus primarily in the construction of the ventral wallin the former, there are no pleural lists and lateral apertural rods, and a reticulum present only in $\mathrm{H}$. erraticus. Also, an outer ancora is present only in mature rhabdosomes of 
H. erraticus. In Holoretiolites, the reticulum overgrowing the proximal ventral and the lateral orifices is absent. Additionally, as noted by Maletz (2008), the genicular elaborations are not developed in Holoretiolites but are common in Neogothograptus, and these two genera differ in the development and orientation of the lateral parietal lists. The seams on the lists of the proximal end of the rhabdosome indicate the presence of membrane covering the proximal ventral orifices and proximal lateral orifices in mature colonies. In young rhabdosomes it is impossible to define them because the seams on lists of the proximal end of the rhabdosome are poorly preserved.

Genus Plectograptus Moberg and Törnquist, 1909 Type species: Retiolites macilentus Törnquist, 1887

Diagnosis (emended from Maletz 2010) Simplified shallow ancora umbrella consisting of two short branches and two long branches: one of these long branches divides once at the theca $1^{2}$ side of the rhabdosome; ancora umbrella has five meshes and fragmentary outlined ancora umbrella rim; no outer ancora; nema not attached to lateral wall, only in Plectograptus robustus is it attached to the nematularium in the distal part of the rhabdosome; proximal ventral orifices are of different sizes, at the theca $1^{2}$ side of the rhabdosome usually larger; proximal lateral orifices big. Ventral wall consists of lips, genicular lists, lateral apertural rods, and mid-ventral lists; mid-ventral lists much thinner than other lists in rhabdosome; genicular processes can be observed in some species; reticulum present only in $P l$. wimani; rhabdosomes usually open-ended, only in $P l$. robustus is it ended by the nematularium.

Included species Retiolites macilentus Törnquist, 1887; Agastograptus robustus Obut and Zaslavskaya, 1983; Retiolites wimani Eisenack, 1951; Plectograptus toernquisti Bates Kozłowska, Maletz, Kirk and Lenz, 2006; Plectograptus mobergi Bates Kozłowska, Maletz, Kirk and Lenz, 2006; Plectograptus trijunctus Bates Kozłowska, Maletz, Kirk and Lenz, 2006.

Remarks Well preserved material from the Gołdap borehole includes the genera $\mathrm{Pl}$. macilentus, Pl. robustus, $P l$. toernquisti, and Pl. mobergi. The arrangement of the ancora umbrella and the course of the ancora umbrella membranes of Plectograptus were described by Bates et al. (2006) on the basis of the occurrence of seams on lists (Fig. 9a). Such a layout of seams and membranes of the ancora umbrella was confirmed by the material collected from the Gołdap borehole (Fig. 7). Furthermore, on the basis of the material from the Gołdap borehole it is observed that, in rare cases, the fragmentary rim of the ancora umbrella can combine into larger fragments (Fig. 7c). In the diagnosis of the genus Plectograptus, Maletz (2010) has shown that Plectograptus had the four main meshes of the ancora umbrella. On the other hand, on the basis of ultrastructural analysis of the material from the Gołdap borehole and material from the northern Germany, Poland, and Canada, Bates et al. (2006) demonstrated that the ancora umbrella has five meshes. The four main meshes attached to the ancora cannot be diagnostic features for Plectograptus, because they are characteristic for all young retiolitids. In remarks on the genus diagnosis, Maletz (2010) stated that the main difference between Spinograptus and Plectograptus consisted in the simpler development of the ancora umbrella, in Plectograptus outlines of the meshes being only partly formed by clathrial lists. On the basis of the material from the Gołdap borehole the author believes that the development of the ancora umbrella of Plectograptus is not only reduced and simpler than that in Spinograptus, but the ancora umbrella also has a different layout of the lists: in Plectograptus the umbrella consists of two short branches and two long branches and one of these branches, at the $1^{2}$ side of the rhabdosome, is divided only once (Figs. 8c, 9a), whereas in Spinograptus it consists of two short branches and two long branches and the branch at the $1^{1}$ side of the rhabdosome is divided once, but the branch at $1^{2}$ side of the rhabdosome is divided twice (Figs. 8d, 9c). So far, the presence of large proximal ventral and lateral orifices has been determined (Maletz 2010; Bates et al. 2006, Fig. 2b). The seams indicating the membranes of the ancora sleeve are visible from the proximal part of the first pleural lists (Fig. 11c), indicating that the proximal lateral orifices are overgrown in large part by membrane and probably had an elongated shape (Fig. 7a). The proximal lateral orifices are bounded above by the membrane of the ancora sleeve and below by the membrane of the ancora umbrella. In rare cases, they are limited by a fragment of the ancora umbrella rim (Fig. 11). The proximal ventral orifices differ in size, that at the theca $1^{2}$ side of the rhabdosome usually being larger than that at the theca $1^{1}$ side.

Genus Spinograptus Bouček and Münch, 1952

Type species: Retiolites spinosus Wood, 1900

Diagnosis (emended from Kozłowska et al. 2012, doi: http://dx.doi.org/10.4202/app.2011.0020) Ancora umbrella consists of two short branches and two long branches, the branch at the $1^{1}$ side of the rhabdosome is divided once, the branch at $1^{2}$ side of the rhabdosome is divided twice; ancora umbrella has seven meshes and full rim; outer ancora present in some species; nema centrally located, in two species in distal part of the rhabdosome is attached to obverse side of the rhabdosome below the appendix; proximal ventral orifices can sometimes have paired genicular processes, in one species Sp. tubothecalis they can be overgrown by reticulum in mature specimens; 


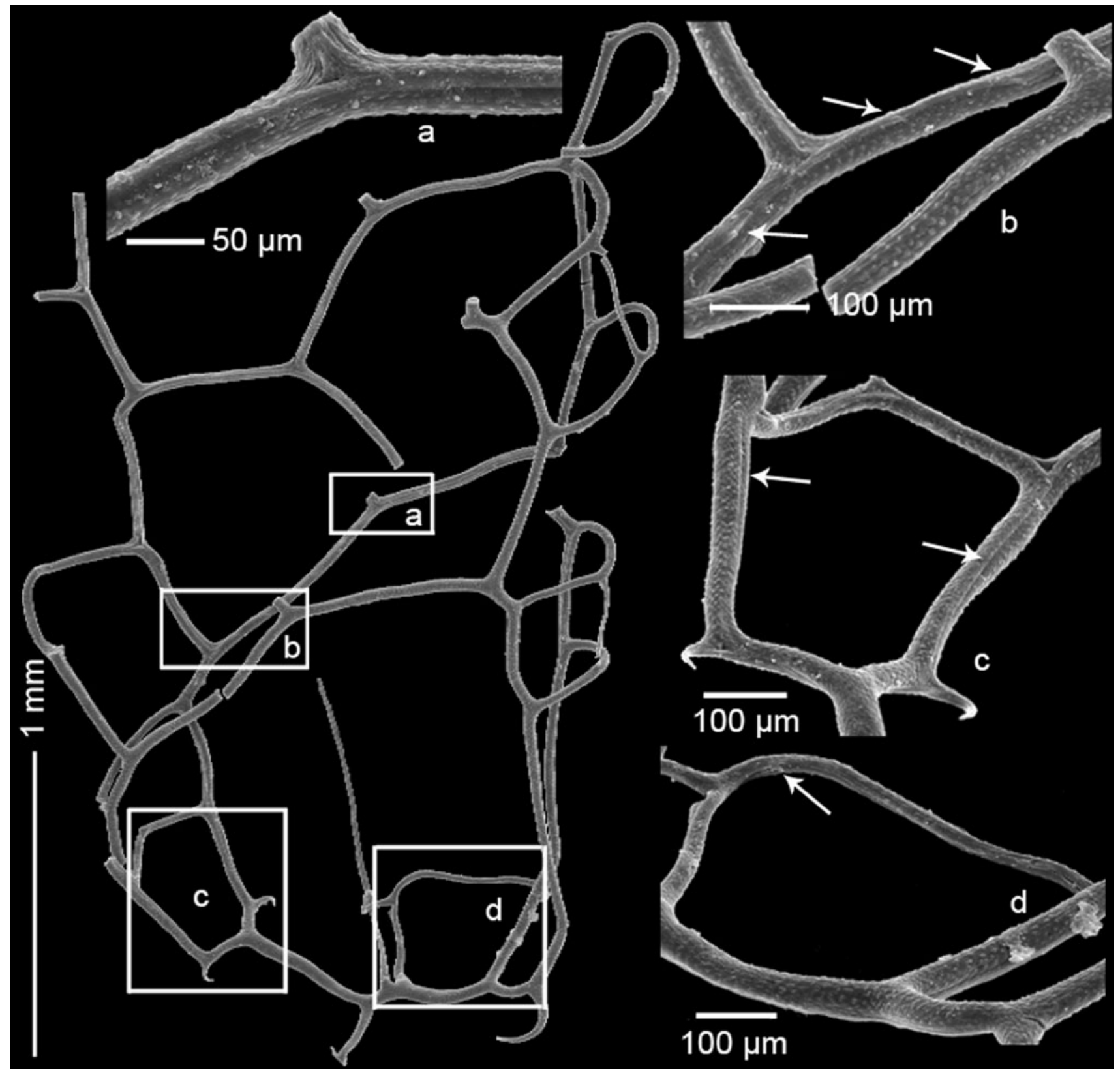

Fig. 11 Plectograptus macilentus (Törnquist, 1887) with ultrastructures indicating the existence of membranes. ZPAL G. 48/4. a Ancora sleeve list with double seams which indicate membranes running distally and proximally, the proximally growing membrane overgrowing the proximal lateral orifice. $\mathbf{b}$ Ancora sleeve list with fusellar increments (arrows) indicating the membrane running toward the

proximal lateral orifices medium sized and shifted toward the $1^{2}$ side of the rhabdosome. Ventral wall is composed of lips, genicular lists, lateral apertural rods and rudimentary mid-ventral lists, in some species with rudimentary transverse rods; ancora sleeve consists of parietal lists forming distinct zigzag pattern; paired reticulo-fusellar apertural processes present; reticulum can be present; rhabdosomes may be open-ended or finite with short appendix; finite proximal end of the rhabdosome, overgrowing the proximal lateral orifice. $\mathbf{c}$ Lists around the proximal ventral orifice with single seams (arrows) indicating the existence of membranes overgrowing the proximal lateral orifices. d Fragment of the ancora umbrella rim with the single seam and the increment (arrow) indicating the ancora umbrella membrane overgrowing this mesh

rhabdosomes may taper distally or, exceptionally, may be parallel-sided with two distal isolated thecae with openings directed distally. In some species the membrane of sicula, thecae, or ancora sleeve can be present.

Included species Retiolites spinosus Wood, 1900; Retiolites clathrospinosus Eisenack, 1951; Holoretiolites (Balticograptus) lawsoni Holland Rickards and Warren, 1969; 
Agastograptus quadratus Lenz, 1993; Spinograptus reticulolawsoni Kozłowska-Dawidziuk, 1997; Spinograptus latespinosus Kozłowska-Dawidziuk, 1997; Spinograptus praerobustus Lenz and Kozłowska-Dawidziuk, 2002; Spinograptus tubothecalis Kozlowska Dobrowolska and Bates, 2012 (http://dx.doi.org/10.4202/app.2011.0020).

Remarks The rich material from the Gołdap borehole includes the species $S p$. spinosus, Sp. clathrospinosus, Sp. reticulolawsoni, and Sp. tubothecalis. Here, the Kozlowska et al. (2012; http://dx.doi.org/10.4202/app.2011.0020) diagnosis is extended by a detailed description of development of the ancora umbrella. The ancora umbrella of Spinograptus is the most complicated among the postlundgreni retiolitid fauna. It is the most branched and it has as many as seven meshes (Figs. 8d, 9c). The aberrant forms are rare: an irregular ancora umbrella with an additional branch at the theca $1^{2}$ side of the rhabdosome and with eight meshes was found in one specimen only (Fig. 10d). The proximal lateral orifices are generally not overgrown by membranes and reticulum. In rare cases of mature specimens, they can be overgrown by single lists of

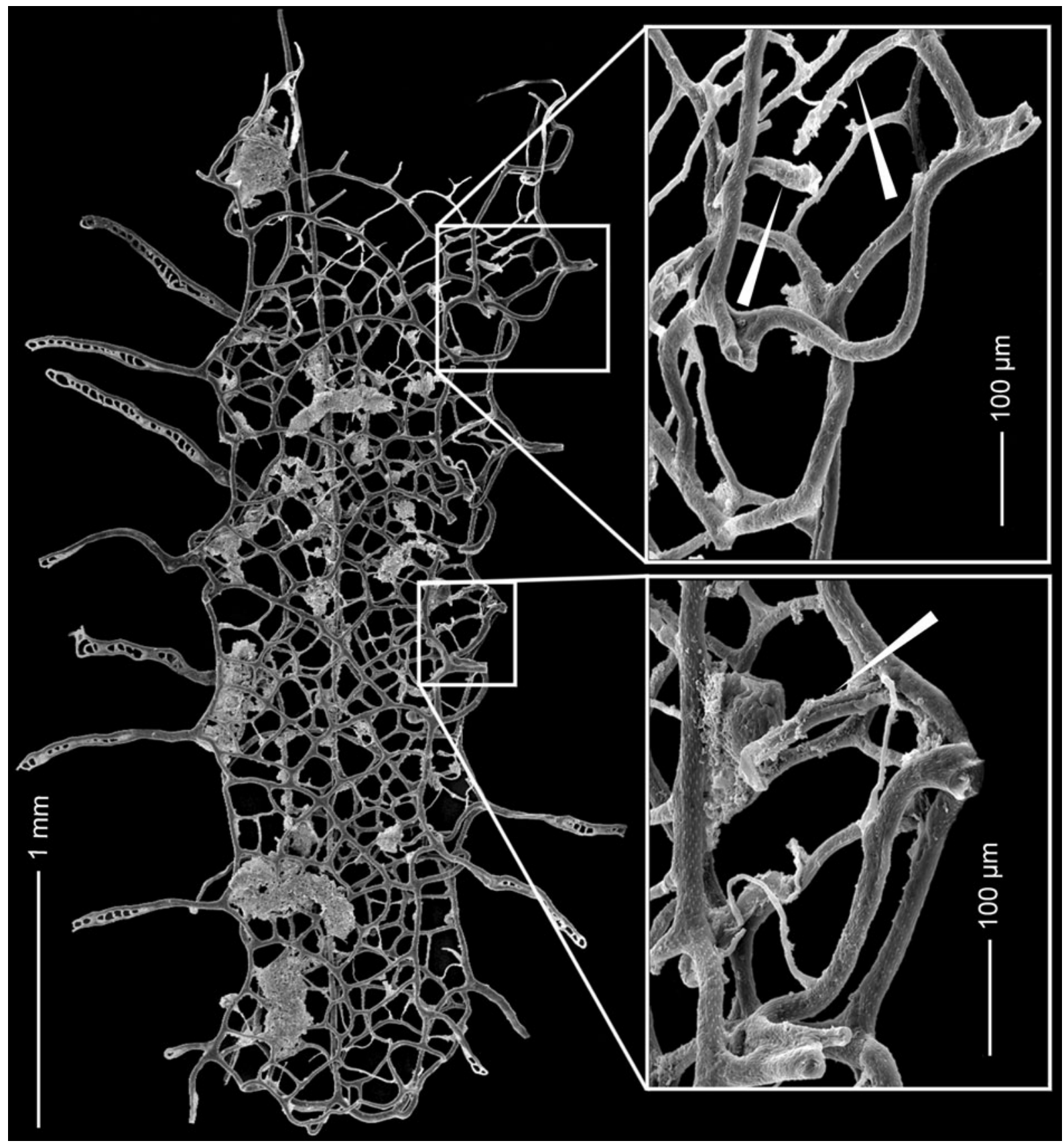

Fig. 12 Spinograptus clathrospinosus (Eisenack, 1951) with well developed transverse rods (arrows). ZPAL G. 48/15 
reticulum. The proximal ventral orifices are usually not overgrown by membranes and reticulum. Only in very mature rhabdosomes of $S p$. tubothecalis, can they be overgrown by reticulum and probably by membranes (Kozłowska et al. 2012; http://dx.doi.org/10.4202/app. 2011.0020). Spinograptus is the only genus occurring after the lundgreni event to have incomplete transverse rods as described in Sp. tubothecalis (Kozłowska et al. 2012; http://dx.doi.org/10.4202/app.2011.0020). This feature is characteristic of the earlier retiolitids occurring before the lundgreni event. In the new material from the Gołdap borehole collected in this study, transverse rods occur in Sp. tubothecalis, Sp. spinosus, and Sp. clathrospinosus also (Fig. 12).

Genus Quattuorgraptus n. gen.

Origin of name: quattuor Latin-four, due to the simple development of the ancora umbrella with only four meshes.

Type species: Retiolites munchi Eisenack, 1951

Diagnosis Simple ancora umbrella consists of four undivided branches, four meshes, and fully developed rim; outer ancora absent; nema not connected to lateral wall of the rhabdosome; proximal ventral orifices can sometimes have paired, short, reticulo-fusellar processes; proximal lateral orifices large and shifted toward the $1^{2}$ side of the rhabdosome. Ventral wall composed of lips, genicular lists, lateral apertural rods, and sometimes rudimentary mid-ventral lists; parietal lists of ancora sleeve form distinct zigzag pattern; paired, reticulo-fusellar genicular processes present, usually split in their medial part, sometimes straight or more complicated; reticulum absent; rhabdosome open-ended.

Included species Retiolites munchi Eisenack, 1951

Remarks Hitherto Quattuorgraptus munchi has been assigned to Spinograptus because it has paired genicular processes and characteristic development of the ancora sleeve. Here, it is suggested that $Q$. munchi does not belong to Spinograptus because it differs mainly in the development of the ancora umbrella (compare Figs. 9c and 9d). The ancora umbrella of $Q$. munchi is simple and consists of four undivided branches, with four meshes and a complete ancora umbrella rim (Fig. $13 \mathrm{a}_{1-2}, \mathrm{~g}_{1}$ ). Spinograptus has a more complicated ancora umbrella, consisting of two short branches and two long branches: the branch at the $1^{1}$ side of the rhabdosome is divided once, the branch at the $1^{2}$ side of the rhabdosome is divided twice. Thus it has seven meshes and a complete ancora umbrella rim (Figs. 8d, 9c). Another feature which differentiates $Q$. munchi from the genus Spinograptus is the width of the lateral wall of the rhabdosome. At the level of the first pair of theca of the lateral wall, $Q$. munchi is from 832 to $871 \mu \mathrm{m}$ wide, whereas in Spinograptus it is from 696 to $826 \mu \mathrm{m}$.
Fig. 13 a-f, h Specimens of Quattuorgraptus munchi (Eisenack, 1951) from the Gołdap borehole. $\mathbf{a}_{1}-\mathbf{a}_{3}$ The longest rhabdosome having three pairs of thecae. ZPAL G. 48/16: $\mathbf{a}_{1}$ Stereopair of the outside view of the ancora umbrella with clear seams. $\mathbf{a}_{2}$ Reconstruction of the ancora umbrella with membranes. Numbers show four meshes of the ancora umbrella. $\mathbf{a}_{3}$ Stereopair of the whole specimen; proximal lateral orifices are marked. b Rhabdosome with three thecae with the proximal ventral orifices marked. ZPAL G. 48/17. $\mathbf{c}_{\mathbf{1}}-\mathbf{c}_{\mathbf{2}}$ ZPAL G. 48/2: $\mathbf{c}_{\boldsymbol{1}}$ Proximal end with clearly visible seams of the ancora umbrella. $\mathbf{c}_{2}$ Increments of the fuselli of the ancora umbrella membranes. d Typical bifurcating reticulo-fusellar thecal process splitting in its medial part. ZPAL G. 48/18. e Complex reticulofusellar thecal process. ZPAL G. 48/19. f The ancora umbrella of a young specimen with four meshes and not fully developed ancora umbrella rim. ZPAL G. 48/20. g1- $\mathbf{g}_{2}$ ZPAL G. 48/21: g1 Young specimen with a long nema not connected to the rhabdosome. $\mathbf{g}_{2}$ Proximal view of the ancora umbrella with clearly visible seams. $\mathbf{h}$ The ancora umbrella of a young specimen of Plectograptus toernquisti Bates, Kozłowska, Maletz, Kirk, and Lenz, 2006 with five meshes. ZPAL G. 48/22

Quattuorgraptus munchi does not have a reticulum (Fig. 13a 3 , b) whereas the different species of Spinograptus have a variably developed reticulum. Spinograptus can have an outer ancora and Q. munchi does not (Fig. 13a-c, f-g).

Quattuorgraptus munchi (Eisenack, 1951) (Figs. 2b, 9d, 13a-g)

1951 Retiolites munchi Eisenack: 138, pl. 22: 9-12, pl. 23: 3-5, pl. 24: 1 .

1983 Agastograptus munchi Obut and Zaslavskaya: 111-112, pl. 22: 4, pl. 26: 1-4.

1995 Spinograptus munchi Kozłowska-Dawidziuk: 316-317, Fig. 31 a, 32 a-b.

2001 Spinograptus munchi Kozłowska-Dawidziuk, Lenz and Štorch: 155, Fig. 5.4-5.6, 5.10, 5.14, 5.16.

2002 Spinograptus munchi Kozłowska-Dawidziuk: 463-464, Fig. 3a, h.

2010 Spinograptus munchi Maletz: 511-512, Fig. 2 o, $5 \mathrm{c}-\mathrm{d}, 7 \mathrm{a}-\mathrm{h}$.

Material Seven specimens with a minimum three pairs of thecae and about 120 smaller fragments of rhabdosomes. Depths: 1,255.0 m, 1,257.0 m-ludensis zone; 1,264.0 m, 1,267.0 m—deubeli zone. ZPAL G. 48/2; 48/16-22.

Diagnosis As for the genus.

Description The longest rhabdosome is $3.91 \mathrm{~mm}$ long with three pairs of thecae (Fig. 13a $a_{3}$ ). The width of the lateral wall $(832-871 \mu \mathrm{m})$ was measured between the pleural lists at the height of the lips of the first pair of thecae, on the level of the second and the third pairs of thecae at 1.07 and $1.08 \mathrm{~mm}$, respectively. The ventral wall slightly extends through the distal end of the rhabdosome. The ancora umbrella is from 588 to $770 \mu \mathrm{m}$ wide and approximately $121 \mu \mathrm{m}$ deep. The proximal ventral orifices 


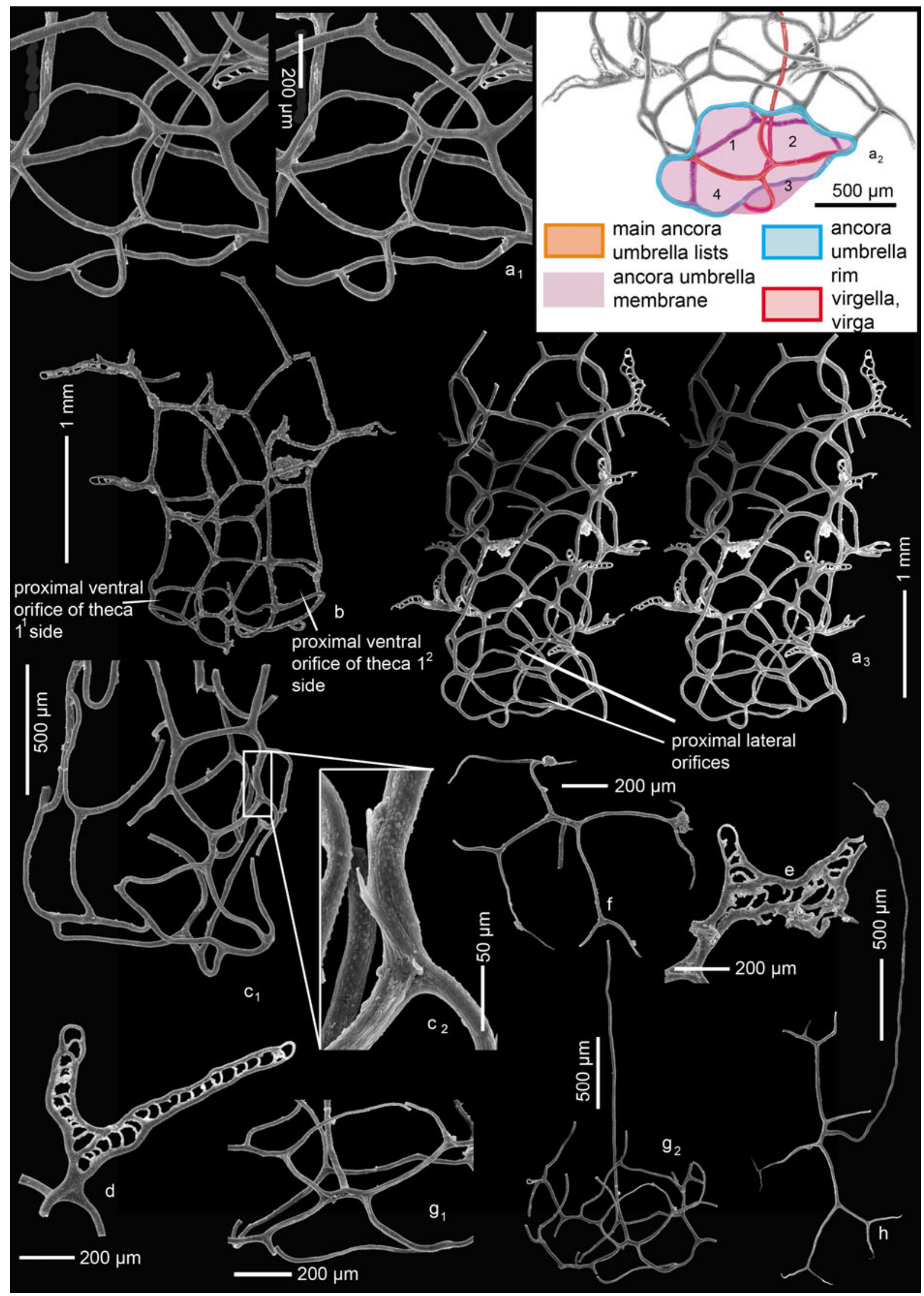


are almost at the same level and usually without genicular processes (Fig. 13b). Only one specimen from 1,257.0 m of the Gołdap borehole has paired reticulo-fusellar processes over the orifice of the $1^{1}$ side of the rhabdosome (Fig. 13a). In all specimens, the orifice at the $1^{1}$ side of the rhabdosome is smaller than the orifice at the $1^{2}$ side (Fig. 13b). The distance from the ancora umbrella to thecal lip at the $1^{1}$ side of the rhabdosome is $804-838 \mu \mathrm{m}$ and that to the thecal lip at the $1^{2}$ side of the rhabdosome is $1.15-1.22 \mathrm{~mm}$. Usually, there are no mid-ventral lists, although, in some specimens, short rudimentary mid-ventral lists occur. There are no transverse rods, although, in a few specimens, the denticles are visible in the place where transverse rods usually occur. The thecal apertures are rectangular; the genicular list is slightly longer than the lip. Apertures have a width of ca. 400-500 $\mu \mathrm{m}$ and a height of ca. 200-250 $\mu \mathrm{m}$. The successive lips are distanced from each other as follows: the first from the second thecae, 616-714 $\mu \mathrm{m}$; the second from the third, 619-711 $\mu \mathrm{m}$; the third from the fourth, $651 \mu \mathrm{m}$. The rhabdosomes have paired reticulo-fusellar genicular processes which usually bifurcate in their medial parts (Fig. 13d). Sometimes there are unbifurcating straight genicular processes or ones of a more complex form (Fig. 13e). These latter occur in the shallowest sample at a depth of $1,255.0 \mathrm{~m}$. The length of shorter arm of a typical process is $400 \mu \mathrm{m}$ and that of the longer arm is $776 \mu \mathrm{m}$. Processes over the proximal ventral orifices are $340 \mu \mathrm{m}$ long. Membranes are not preserved.

Remarks On the basis of material from a glacial erratic boulder from Rügen Island, Maletz (2010) reported that Spinograptus munchi has a shallow ancora umbrella formed by four central meshes and a number of smaller outer meshes, which are often poorly and incompletely outlined by a thin ancora umbrella rim. According to him, the ancora umbrella rim is difficult to trace. In this paper, on the basis of detailed analysis of seams of the proximal end of $Q$. munchi rhabdosomes, it is shown above that the ancora umbrella of $Q$. munchi consisted of four meshes only. It is also suggested that the material from Rügen Island is of younger astogenetic stages than the material from the Gołdap borehole, because the latter contains specimens with thicker lists and a fully developed ancora umbrella rim. The material from Rügen Island contains rhabdosomes with poorly preserved proximal ends and thin lists. Therefore, the description of this part of the rhabdosomes could not be unequivocal. Quattuorgraptus munchi is constructed of thick lists and does not have a reticulum and an outer ancora. In this regard and by similarity of shape of rhabdosomes (the walls are almost parallel) it resembles the genus Plectograptus, especially Pl. robustus (this species has paired genicular processes similar to Q. munchi). These two species differ in the development of the ancora umbrella. This difference is already visible in specimens of young astogenetic stages of the colony when the first pair of thecae are not yet developed (Fig. 13f, h). The ancora umbrella of $Q$. munchi consists of four arms of equal length surrounded by the ancora umbrella rim (Fig. 13f), whereas the ancora umbrella in Pl. robustus consists of two short branches and two long branches and one of these branches is divided once and the acora umbrella rim is not developed (Fig. 13h). Q. munchi does not have mid-ventral lists, which are well developed in Plectograptus.

\section{Conclusions}

Exceptionally well preserved post-lundgreni event retiolitids from the Gołdap borehole of Poland (Baltica) were studied under the scanning electron microscope. As a result, two types of lists with single and double seams are distinguished. On the basis of detailed analysis of seams on lists, reconstructions of the proximal ends of rhabdosomes with the arrangements of membranes of five retiolitid genera are presented.

The development of the proximal ends of the described genera differs substantially (except for Neogothograptus and Holoretiolites). It seems that the ancora umbrella of Spinograptus is the most complex among the post-lundgreni retiolitid genera: it has seven meshes and has a fully developed rim. The ancora umbrella of Quattuorgraptus $\mathrm{n}$. gen. has only four meshes and a full rim. The ancora umbrella of Neogothograptus and Holoretiolites has six meshes and a full rim. Although the two genera have an identical construction of the ancora umbrella, they differ from each other by the structure of the ancora sleeve and ventral walls. The Plectograptus ancora umbrella has five meshes without a rim; in rare cases only is a small fragment of rim developed. After tracking the proximal seams in Plectograptus it seems that its large proximal lateral orifices were probably much smaller than described, and they were of slit-shape rather than oval.

Such large differences in development of the proximal end of the rhabdosome may indicate a change in behavior of the first zooid.

On the basis of analysis of the ancora umbrella seams, Spinograptus munchi can be assigned to the new genus Quattuorgraptus.

Significant differences in seam development are observed between the two groups of retiolitids, occurring before and after the lundgreni event. The earlier retiolitids have deep, distinct, and clearly visible seams; the later ones have less pronounced, shallow seams which are easy to confuse with bandages. The increments of the older retiolitids are more often preserved than those of younger ones. 
Acknowledgments I would like to thank Anna Kozłowska (Institute of Paleobiology Polish Academy of Sciences, Poland) for helpful discussions, constructive comments, and for kindly reading the manuscript. I am very grateful to Denis Bates for correcting the English text and to Jörg Maletz for correcting the German text. I thank the reviewers Jörg Maletz from State University (Buffalo, USA) and Denis Bates from University of Wales (Aberystwyth, UK) who made useful and thoughtful comments. Financial support was given by The Minister of Science and Higher Education, decision 499/N-NSERC/2009/0. The SEM pictures were made in Institute of Paleobiology Polish Academy of Sciences on Philips XL.

Open Access This article is distributed under the terms of the Creative Commons Attribution License which permits any use, distribution, and reproduction in any medium, provided the original author(s) and the source are credited.

\section{References}

Bates, D.E.B. 1987. The construction of graptolite rhabdosomes in the light of ultrastructural studies. Indian Journal of Geology 59: $1-28$.

Bates, D.E.B., and N.H. Kirk. 1978. Contrasting modes of construction of retiolite-type rhabdosomes. Acta Palaeontologica Polonica 23: 427-448.

Bates, D.E.B., and N.H. Kirk. 1992. The ultrastructure, mode of construction and functioning of a number of Llandovery ancorate and retiolitid graptolites. Modern Geology 17: 1-270.

Bates, D.E.B., and N.H. Kirk. 1997. The ultrastructure, construction and functioning of the genera Stomatograptus and Retiolites, with an appendix on the incremental construction of the rhabdosome in Petalolithus, and its comparison with that of the thecal framework in Retiolites and in Stomatograptus. Institute of Geography and Earth Sciences, University of Wales, Aberystwyth Publication 10: 1-168.

Bates, D.E.B., A. Kozłowska, and A.C. Lenz. 2005. Silurian retiolitid graptolites: Morphology and evolution. Acta Palaeontologica Polonica 50: 705-720.

Bates, D.E.B., A. Kozłowska, J. Maletz, N.H. Kirk, and A.C. Lenz. 2006. The Silurian retiolitid graptolite Plectograptus: New observations and new species. Acta Palaeontologica Polonica 51: 525-540.

Bouček, B., and A. Münch. 1952. Retioliti středoevropského svrchního wenloku a ludlowu. Sbornık Ústředniho Ústavu geologického, oddil paleontologicky 19: 1-151.

Eisenack, A. 1951. Retioliten aus dem Graptolithengestein. Palaeontographica 100: 129-163.

Holland, C.H., R.B. Rickards, and P.T. Warren. 1969. The Wenlock graptolites of the Ludlow district, Shropshire, and their stratigraphical significance. Palaeontology 12: 663-683.

Kozłowska-Dawidziuk, A. 1995. Silurian retiolitids of the East European Platform. Acta Palaeontologica Polonica 40: 261-326.

Kozłowska-Dawidziuk, A. 1997. Retiolitid graptolite Spinograptus from Poland and its membrane structures. Acta Palaeontologica Polonica 42: 391-412.

Kozłowska-Dawidziuk, A. 2002. Agastograptus, a synonym of Plectograptus (Retiolitida, Graptolithina). Acta Palaeontologica Polonica 47: 459-467.

Kozłowska-Dawidziuk, A. 2004. Evolution of retiolitid graptolites: a synopsis. Acta Palaeontologica Polonica 49: 505-518.

Kozłowska-Dawidziuk, A., and A.C. Lenz. 2001. Evolutionary developments in the Silurian Retiolitidae (Graptolites). Journal of the Czech Geological Society 46: 227-238.

Kozłowska-Dawidziuk, A., A.C. Lenz, and P. Štorch. 2001. Upper Wenlock and Lower Ludlow (Silurian), post- extinction graptolites, Všeradice section, Barrandian area, Czech Republic. Journal of Paleontology 75: 147-164.

Kozłowska-Dawidziuk, A., A.C. Lenz, and D.E.B. Bates. 2003. A new classification of ancorate diplograptids. In: G. Ortega and G.F. Acenolaza eds., Proceeding of the 7th International Graptolite Conference and Field Meeting of the Subcommission on Silurian Stratigraphy: 49-53. Consejo Nacional de Investigaciones Cientificas y Técnicas Facultad de Ciencias Naturales e Instituto Miguel Lillo Universidad Nacional de Tucumán,Argentina.

Kozłowska-Dawidziuk, A., A.C. Lenz, and M. Melchin. 2009. Evolution of the retiolitid Neogothograptus (Graptolithina) and its new species from the upper Wenlock of Poland, Baltica. Acta Palaeontologica Polonica 54: 423-434.

Kozłowska, A., K. Dobrowolska, and D.E.B. Bates. 2012. A new type of colony in Silurian (upper Wenlock) retiolitid graptolite Spinograptus from Poland. Acta Palaeontologica Polonica. http://dx.doi.org/10.4202/app.2011.0020

Lapworth, C. 1873. On an improved classification of the Rhabdophora. Geological Magazine 10(500-504): 555-560.

Lenz, A.C. 1993. Late Wenlock and Ludlow (Silurian) Plectograptinae (retiolitid graptolites), Cape Phillips Formation, Arctic Canada. Bulletins of American Paleontology 104: 1-52.

Lenz, A.C. 1994a. Uppermost Wenlock and lower Ludlow plectograptine graptolites, Arctic Islands, Canada: new isolated material. Journal of Paleontology 68: 851-860.

Lenz, A.C. 1994b. A sclerotized retiolitid, and its bearing on origin and evolution of Silurian retiolitid graptolites. Journal of Paleontology 68: 1344-1349.

Lenz, A.C., and A. Kozłowska-Dawidziuk. 2002. Upper Homerian (Upper Wenlock, Silurian) graptolites from Arctic Canada. Journal of Paleontology 76: 321-346.

Lenz, A.C., and A. Kozłowska-Dawidziuk. 2004. Ludlow and Pridoli (Upper Silurian) Graptolites from the Arctic Islands, Canada, 141. Ottawa: National Research Council of Canada.

Lenz, A.C., and R. Thorsteinsson. 1997. Fusellar banding in Silurian retiolitid graptolites. Journal of Paleontology 71: 917-920.

Maletz, J. 2008. Retiolitid graptolites from the collection of Hermann Jaeger in the Museum für Naturkunde, Berlin (Germany). I. Neogothograptus and Holoretiolites. Paläontologische Zeitschrift 82: 285-307.

Maletz, J. 2010. Retiolitid graptolites from the collection of Hermann Jaeger II: Cometograptus, Spinograptus and Plectograptus. Paläontologische Zeitschrift 84: 501-522.

Mitchell, C.E. 1987. Evolution and phylogenetic classification of the Diplograptacea. Palaeontology 30: 353-405.

Moberg, J.C., and S.L. Törnquist. 1909. Retiolitoidea från Skånes Colonusskiffer. Sveriges Geologiska Undersökning (C) 213: 1-20.

Münch, A. 1931. Retiolites mancki. Ein neuer Retiolites aus dem norddeutschen Geschiebe.-23. Bericht der Naturwissenschaftlichen Gesellschaft zu Chemnitz, 35-42, 1 pl.

Obut, A.M. and N. Zaslavskaya. 1983. Families of retiolitids and their phylogenetic relationships. In: Dagys, A.S. and V.N. Dubatolov. eds.. Morfologia I sistematika bespozvonocnyh fanerozoa, 102-113. Izdatelstvo Nauka, Moskva. (cited from A. Kozłowska-Dawidziuk 2002). [in Russian, for English translation see Obut and Zaslovskaya, 1986].

Tomczykowa, E., and H. Tomczyk. 1979. Middle Silurian in the Podlasie Depression (Eastern Poland). Biuletyn Instytutu Geologicznego 318: 59-88.

Törnquist, S.L. 1887. Anteckningar om de äldre paleozoiska leden i Ostthüringen och Vogtland. Geologiska Förennigens i Stockholm Förhandlingar 9: 471-492.

Wood, E.M.R. 1900. The Lower Ludlow formation and its graptolite fauna. Quarterly Journal of the Geological Society of London 56: 415-492. 